DOI https://doi.org/10.30525/978-9934-588-80-8-2.45

\title{
КОНТЕКСТНИЙ ПІДХІД ДО ВИКЛАДАННЯ АНГЛІЙСЬКОЇ МОВИ ПРОФЕСІЙНОГО СПРЯМУВАННЯ
}

\author{
Риб'як В. В. \\ старший викладач кафедри авіаџійної англійської мови \\ Харківський наиіональний університет \\ Повітряних Сил імені Івана Кожедуба
}

Ревуцька С. М.

професор кафедри філології, перекладу та стратегічних комунікацій Національна академія Національної Гвардї

м. Харків, Украӥна

Сьогодення вимагає перегляду підходів до викладання англійської мови професійного спрямування. Вже не один рік ведуться розмови про необхідність формування у студентів так званих «soft skills», а саме вміння швидко реагувати на виклики сучасного життя та знаходити шляхи вирішення проблем, мислити творчо та нестандартно, мати навички роботи в команді для досягнення спільної мети. Невідворотні зміни, які відбуваються у Збройних Силах України, а саме поступовий перехід до стандартів НАТО, спільні навчання українських військових 3 представниками іноземних армій в межах співробітництва із альянсом, змушує все більше уваги приділяти рівню володіння англійською мовою. Відповідно, викладачі англійської мови професійного спрямування, навчаючи студентів мові і тому, як саме вона функціонує, мають також створювати на занятті умови, які б сприяли залученню англійської мови до формування у студентів зазначених «soft skills». На нашу думку, одним із підходів до викладання англійської мови професійного спрямування, який здатний допомогти викладачеві у сучасних умовах, може стати контекстне навчання.

Метою цієї роботи $\epsilon$ - обгрунтувати необхідність застосування контекстного підходу для створення на заняттях умов, що максимально відповідають сучасним, а також узагальнити досвід щодо використання контекстного підходу на заняттях 3 англомовної підготовки авіаційних фахівців.

Вивченням проблеми впровадження контекстного підходу до навчання займаються як зарубіжні, так і вітчизняні педагоги і науковці. В своїх роботах зарубіжні автори наводять приклади успішного застосування контекстного підходу до навчання та наголошують, що 
такий підхід, по-перше, сприяє формуванню у студентів необхідних навиків, які роблять їх конкурентоспроможними в умовах сучасного ринку праці [6], по-друге, збільшує вмотивованість до навчання: чим більше матеріал пристосовано до потреб та інтересів студентів, тим активнішими і зацікавленими вони $є$ на занятті [4, 7]. Вітчизняні науковці все більше і більше уваги приділяють цій проблематиці, але наразі роботи у зазначеній галузі не $є$ такими чисельними, і присвячені, в основному, розробці теоретичного підгрунтя для застосування контекстного підходу до навчання $[1,2,3]$.

Враховуючи результати досліджень як зарубіжних, так і вітчизняних педагогів та науковців, зазначимо, що контекстне навчання полягає в адаптації навчальних матеріалів таким чином, щоб створити на занятті умови, які були б максимально наближені до реальних, відповідали інтересам майбутньої професії, враховували би відповідний індивідуальний рівень кожного 3 тих, хто навчається, та сприяли б залученню до навчального процесу їх особистого досвіду.

Протягом певного періоду часу на базі Харківського національного університету Повітряних Сил проводився методичний експеримент. У експерименті брали участь курсанти двох навчальних груп. На заняттях контрольної групи використовувались виключно матеріали підручників та завдання, які пропонувались авторами цих підручників. На заняттях у експериментальній групі був застосований контекстний підхід до навчання. Контекстний підхід передбачав адаптацію навчальних матеріалів. Створюючи адаптовані навчальні матеріали, ми враховували рівень підготовки кожного курсанта навчальної групи, інтереси майбутньої професії, попередній особистий досвід тих, хто навчається, та робили все можливе, щоб максимально наблизити умови навчання до реальних.

Необхідно зазначити, що, як правило, середньостатистичний рівень володіння англійською мовою серед курсантів $\epsilon$ невисоким, недостатнім $\epsilon$ і рівень мотивації до ії вивчення, а також обмеженою $\epsilon$ сфера пізнавальних інтересів. У таких випадках матеріали підручника, які містять загальні питання та передбачені для широкого кола студентів, залишають байдужими курсантів з низьким рівнем базової підготовки. Такі курсанти не готові висловлювати власну точку зору, а інколи взагалі неохоче приступають до опрацювання стандартних вправ із підручників.

Результати проведеного експерименту підтвердили, що застосування контекстного підходу сприяє вирішенню зазначених проблем і перш за все підвищенню мотивації. Експеримент показав, що курсанти, які володіли англійською мовою на достатньому і середньому рівні, охоче 174 
працювали як із матеріалом підручника, так із матеріалами, підготовленими для заняття в рамках контекстного навчання. Але серед курсантів 3 недостатнім рівнем підготовки більшу активність i зацікавленість демонструвала та група, яка працювала із завданнями, що враховували їх попередній досвід, апелювали до емоцій і почуттів, які були пов'язані з реальними ситуаціями з їхнього життя.

Курсанти експериментальної групи охоче долучались до створення діалогів, які відтворювали реальні ситуації та відображали їх спосіб життя, особливості несення служби та труднощі військової дисципліни, а також охоче розповідали про свої права і обов'язки у відповідності до посади, яку кожен курсант займає у підрозділі. У курсантів цієї групи не визивало труднощів створення власного уявного послужного списку ані в усній, ані в письмовій формі; курсанти були у змозі моделювати різного роду ситуації. Зазначене свідчить про те, що контекстний підхід незамінний в умовах формування дискурсного компоненту комунікативної компетенції. Курсанти активно долучались до висловлювання власної думки (як під час говоріння, так і під час письма) не тільки на рівні окремих речень, а і на рівні монологу, що складався з низки думок, поєднаних між собою за допомогою відповідних засобів англійської мови.

Результати проведеного експерименту довели, що застосування адаптованих навчальних матеріалів під час вивчення англійської мови професійного спрямування в межах контекстного підходу до навчання, сприяло тому, що курсанти виявляли готовність висловлюватись засобами іноземної мови, активно долучались до групової роботи, а також намагались відтворити власний досвід та говорити щиро.

Таким чином, застосування контекстного підходу шляхом адаптації навчальних матеріалів для створення на заняттях умов максимально наближених до реальних 3 урахуванням як майбутньої професійної спеціалізації, так і рівня підготовки кожного курсанта навчальної групи, $\epsilon$ вимогою часу. Використання адаптованих комунікативних вправ на заняттях 3 англійської мови професійного спрямування у військово-технічних закладах вищої освіти сприяє формуванню необхідної комунікативної компетенції у майбутніх фахівців, створює додаткову мотивацію, підвищує показники рівня успішності навчання, залучає курсантів до вирішення завдань безпосередньо пов'язаних 3 їх майбутньою професією.

\section{Література:}

1. Вишневська К. Контекстне навчання іноземної мови як чинник успішності формування професійної компетенції майбутніх фахівців 
економічного профілю. Проблеми підготовки сучасного вчителя. 2013. № 8 (Ч. 2 ). С. 143-151.

2. Мельник А. Контекстне навчання у процесі професійного іншомовного спілкування студентів немовних спеціальностей. Витоки педагогічної майстерності. Серія: Педагогічні науки. 2012. Вип. 10. C. 191-196.

3. Мирончук Н.М. Контекстний підхід у підготовці студентів до професійної діяльності у зарубіжній педагогічній теорії. Креативна педагогіка. 2018. Вип. 13. С. 95-101.

4. Ambrose, Valerie K.; Davis, C. Amelia; Ziegler, Mary F. A Framework of Contextualized Teaching and Learning: Assisting Developmental Education Instructors, Adult Education Research Conference: 2013 conference proceedings (St Louis, MO). URL: https://newprairiepress.org/aerc/2013/papers/1 (Дата звернення 17.06.2020).

5. Beder H., Medina P. Classroom Dynamics in Adult Literacy Education: NCSALL Reports \#18. Boston, 2001. 128 p. URL: https://www.govinfo.gov/content/pkg/ERIC-ED465026/pdf/ERICED465026.pdf (Дата звернення 05.05.2020)

6. Berns R. G., Erickson, P. M. Contextual Teaching and Learning: Preparing Students for the New Economy. The Highlight Zone: Research @ Work No. 5. Columbus, OH, 2001. 9 p. URL: https://files.eric.ed.gov/ fulltext/ED452376.pdf (Дата звернення 17.02.2020).

7. Perin D. Facilitating Student Learning Through Contextualization. Assessment of Evidence Series. CCRC Working Paper No. 29. New York: Columbia University, 2011. 62 p. URL: https://ccrc.tc.columbia.edu/ media/k2/attachments/facilitating-learning-contextualization-workingpaper.pdf (Дата звернення 16.02.2020).

8. Sears S. Introduction to Contextual Teaching and Learning. Bloomington, Indiana, 2003. 53 p. URL http://teacherlink.ed.usu.edu/ yetcres/catalogs/reavis/ 504.pdf (Дата звернення 05.06.2020). 